NBER WORKING PAPER SERIES

\title{
IS U.S. ECONOMIC GROWTH OVER? FALTERING INNOVATION CONFRONTS THE SIX HEADWINDS
}

\author{
Robert J. Gordon \\ Working Paper 18315 \\ http://www.nber.org/papers/w18315 \\ NATIONAL BUREAU OF ECONOMIC RESEARCH \\ 1050 Massachusetts Avenue \\ Cambridge, MA 02138 \\ August 2012
}

This research has been supported by the Kauffman Foundation. Many facts and relationships highlighted here are based on my book in progress, Beyond the Rainbow: The American Standard of Living Since the Civil War, under contract to the Princeton University Press. To limit the scope of this short paper, only a limited number of historical references and citations are included here. All others are provided in the book manuscript. I am grateful to Marius Malkevicius and Andrew Sabene for their indispensable research assistance, and to David Warsh for helpful comments. This paper originates in a presentation that has been given to numerous audiences over the past year, and I am grateful to members of those audiences for asking provocative questions and making helpful suggestions in the Q\&A sessions. The views expressed herein are those of the author and do not necessarily reflect the views of the National Bureau of Economic Research.

NBER working papers are circulated for discussion and comment purposes. They have not been peerreviewed or been subject to the review by the NBER Board of Directors that accompanies official NBER publications.

(C) 2012 by Robert J. Gordon. All rights reserved. Short sections of text, not to exceed two paragraphs, may be quoted without explicit permission provided that full credit, including $(\mathbb{C}$ notice, is given to the source. 
Is U.S. Economic Growth Over? Faltering Innovation Confronts the Six Headwinds

Robert J. Gordon

NBER Working Paper No. 18315

August 2012

JEL No. D24,E2,E66,J11,J15,O3,O31,O4,Q43

\begin{abstract}
$\underline{\text { ABSTRACT }}$
This paper raises basic questions about the process of economic growth. It questions the assumption, nearly universal since Solow's seminal contributions of the 1950s, that economic growth is a continuous process that will persist forever. There was virtually no growth before 1750, and thus there is no guarantee that growth will continue indefinitely. Rather, the paper suggests that the rapid progress made over the past 250 years could well turn out to be a unique episode in human history. The paper is only about the United States and views the future from 2007 while pretending that the financial crisis did not happen. Its point of departure is growth in per-capita real GDP in the frontier country since 1300, the U.K. until 1906 and the U.S. afterwards. Growth in this frontier gradually accelerated after 1750, reached a peak in the middle of the 20th century, and has been slowing down since. The paper is about "how much further could the frontier growth rate decline?"
\end{abstract}

The analysis links periods of slow and rapid growth to the timing of the three industrial revolutions (IR's), that is, IR \#1 (steam, railroads) from 1750 to 1830; IR \#2 (electricity, internal combustion engine, running water, indoor toilets, communications, entertainment, chemicals, petroleum) from 1870 to 1900; and IR \#3 (computers, the web, mobile phones) from 1960 to present. It provides evidence that IR \#2 was more important than the others and was largely responsible for 80 years of relatively rapid productivity growth between 1890 and 1972. Once the spin-off inventions from IR \#2 (airplanes, air conditioning, interstate highways) had run their course, productivity growth during 1972-96 was much slower than before. In contrast, IR \#3 created only a short-lived growth revival between 1996 and 2004. Many of the original and spin-off inventions of IR \#2 could happen only once - urbanization, transportation speed, the freedom of females from the drudgery of carrying tons of water per year, and the role of central heating and air conditioning in achieving a year-round constant temperature.

Even if innovation were to continue into the future at the rate of the two decades before 2007, the U.S. faces six headwinds that are in the process of dragging long-term growth to half or less of the 1.9 percent annual rate experienced between 1860 and 2007. These include demography, education, inequality, globalization, energy/environment, and the overhang of consumer and government debt. A provocative "exercise in subtraction" suggests that future growth in consumption per capita for the bottom 99 percent of the income distribution could fall below 0.5 percent per year for an extended period of decades.

Robert J. Gordon

Department of Economics

Northwestern University

Evanston, IL 60208-2600

and NBER

rjg@northwestern.edu 


\section{Introduction}

The prospects for future long-run U.S. economic growth were already dismal in 2007 but were little noticed in the continuing euphoria over the invention of the Internet and the related developments in information technology and communications (ICT). This article pulls back from the past five years of financial crisis to pose a question with implications that will persist for decades even if the current international economic disorder is eventually resolved.

This article is about U.S. economic growth through 2007 and the future post-2007 path of potential or trend output for the subsequent 20 to 50 years. The analysis abstracts almost entirely from the negative events that have occurred since 2007. We deliberately ignore the separate questions of whether the recession and slow recovery have pulled down the trend growth rate output, and the size of the "gap" between the trend path and actual real GDP.

The ideas developed here are unorthodox yet worth pondering. They are applied only in the context of the United States, because the worldwide frontier of productivity and the standard of living have been carved out by the U.S. since the late $19^{\text {th }}$ century. If growth of the U.S. productivity frontier slows down, other nations may move ahead, or the slowing frontier could reduce the opportunities for future growth by all nations as the pace of productivity growth in the U.S. fades out.

The article makes these basic points:

1. Since Solow's seminal work in the 1950s, economic growth has been regarded as a continuous process that will persist forever. But there was virtually no economic growth before 1750 , suggesting that the rapid progress made over the past 250 years could well be a unique episode in human history rather than a guarantee of endless future advance at the same rate.

2. The frontier established by the U.S. for output per capita, and the U. K. before it, gradually began to grow more rapidly after 1750, reached its fastest growth rate in the middle of the $20^{\text {th }}$ century, and has slowed down since. It is in the process of slowing down further.

3. A useful organizing principle to understand the pace of growth since 1750 is the sequence of three industrial revolutions. The first (IR \#1) with its main inventions between 1750 and 1830 created steam engines, cotton spinning, and railroads. The second (IR \#2) was the most important, with its three central inventions of electricity, the internal combustion engine, and running water with indoor plumbing, in the relatively short interval of 1870 to 1900 . Both the first two revolutions required about 100 years for their full effects to percolate through the economy. During the two decades 1950-70 the benefits of the IR \#2 were still transforming the economy, including air conditioning, home appliances, and the interstate highway system. After 1970 productivity growth slowed markedly, most plausibly because the main ideas of IR \#2 had by and large been implemented by then. 
4. The computer and Internet revolution (IR \#3) began around 1960 and reached its climax in the dot.com era of the late 1990s, but its main impact on productivity has withered away in the past eight years. Many of the inventions that replaced tedious and repetitive clerical labor by computers happened a long time ago, in the 1970s and 1980s. Invention since 2000 has centered on entertainment and communication devices that are smaller, smarter, and more capable, but do not fundamentally change labor productivity or the standard of living in the way that electric light, motor cars, or indoor plumbing changed it.

5. The article suggests that it is useful to think of the innovative process as a series of discrete inventions followed by incremental improvements which ultimately tap the full potential of the initial invention. For the first two industrial revolutions, the incremental follow-up process lasted at least 100 years. For the more recent IR \#3, the follow-up process was much faster. Taking the inventions and their follow-up improvements together, many of these processes could happen only once. Notable examples are speed of travel, temperature of interior space, and urbanization itself.

6. The benefits of ongoing innovation on the standard of living will not stop and will continue, albeit at a slower pace than in the past. But future growth will be held back from the potential fruits of innovation by six "headwinds" buffeting the U.S. economy, some of which are shared in common with other countries and others are uniquely American. Future growth in real GDP per capita will be slower than in any extended period since the late $19^{\text {th }}$ century, and growth in real consumption per capita for the bottom 99 percent of the income distribution will be even slower than that.

The headwinds include the end of the "demographic dividend;" rising inequality; factor price equalization stemming from the interplay between globalization and the Internet; the twin educational problems of cost inflation in higher education and poor secondary student performance; the consequences of environmental regulations and taxes that will make growth harder to achieve than a century ago; and the overhang of consumer and government debt. All of these problems were already evident in 2007, and it simplifies our thinking about long-run growth to pretend that the post-2007 crisis did not happen. ${ }^{1}$

The audacious idea that economic growth was a one-time-only event has no better illustration than transport speed. Until 1830 the speed of passenger and freight traffic was limited by that of "the hoof and the sail" and increased steadily until the introduction of the Boeing 707 in 1958. Since then there has been no change in speed at all and in fact airplanes fly slower now than in 1958 because of the need to conserve fuel.

\footnotetext{
${ }^{1}$ Since 2007 the overhang of government debt has become much larger, while household debt has declined substantially. The ratio of government debt (held by the public) to GDP increased from 36.0 to 70.1 percent of GDP between 2007:Q4 and 2012:Q1, while over the same period household liabilities declined from 133.4 to 109.6 percent of disposable personal income. Sources for the numerator of these ratios is the FRED database and for the denominator are NIPA tables 1.1.5 and 2.1.
} 
Other one-time-only changes included the transition from animal to machine propulsion that freed the city streets from disease-causing animal waste; from outhouses to indoor plumbing; from housewives carrying buckets of water, coal, and wood into the house to the modern world of running water and sewer systems; from interior cold and heat to uniform indoor temperatures made possible by central heating and air conditioning; and many more one-time-only inventions. This may seem obvious about horses, outhouses, speed, and temperature, but once you accept that, you're drawn into the central theme of this article: economic growth may not be a continuous long-run process that lasts forever.

This article concerns only the United States and has no necessary implications for other countries, which face a different mix of headwinds. The article begins with an examination of long-run growth back to 1300 in the context of the three industrial revolutions. It then provides a few details about the magnitude of change brought about by the first two industrial revolutions, particularly IR \#2.

The treatment of the computer revolution (IR \#3) emphasizes the large number of laborsaving improvements made possible by electronics years before the invention and diffusion of the Internet in the late 1990s. A thought experiment is provided to provoke a new perspective on the inventions of the past decade with those of IR \#2. The paper then turns to the six headwinds faced by the U.S. economy and briefly considers a few of the available solutions that might be considered to address them.

\section{The Super-Long Run Since the Year 1300}

The interpretation of past economic growth is anchored by the three industrial revolutions. The first (IR \#1) centered in 1750-1830 from the inventions of the steam engine and cotton gin through the early railroads and steamships, but much of the impact of railroads on the American economy came later between 1850 and 1900. At a minimum it took 150 years for IR \#1 to have its full range of effects.

The second industrial revolution (IR \#2) within the years 1870-1900 created within just a few years the inventions that made the biggest difference to date in the standard of living. Electric light and a workable internal combustion engine were invented in a three-month period in late 1879. The number of municipal waterworks providing fresh running water to urban homes multiplied tenfold between 1870 and 1900. The telephone, phonograph, and motion pictures were all invented in the 1880s. The benefits of IR \#2 included subsidiary and complementary inventions, from elevators, electric machinery and consumer appliances; to the motorcar, truck, and airplane; to highways, suburbs, and supermarkets; to sewers to carry the wastewater away. All this had been accomplished by 1929, at least in urban America, although it took longer to bring the modern household conveniences to small towns and farms. Additoinal "follow-up" inventions continued and had their main effects by 1970, including 
television, air conditioning, and the interstate highway system. The inventions of IR \#2 were so important and far-reaching that they took a full 100 years to have their main effect.

The third revolution (IR \#3) is often associated with the invention of the web and Internet around 1995. But in fact electronic mainframe computers began to replace routine and repetitive clerical work as early as 1960 . The treatment below of IR \#3 includes examples of the many electronic laborsaving inventions and convenience services that already were widely available before 1995.

With the timing of the three revolutions in place, we can now interpret history with a graph that links together many decades of dedicated research by economic historians to provide data on real output per capita through the ages. Figure 1 displays the record back to the year 1300 and traces the "frontier" of per-capita real GDP for the leading nation. The blue line represents the U. K. through 1906 (approximately the year when the U.S. caught up) and the red line the U.S. from then through 2007. Heroic efforts by British economic historians have established a rough estimate that the U. K. grew at 0.2 percent per year for the four centuries through $1700 .^{2}$ The graph shows striking absence of the lack of progress; there was almost no economic growth for four centuries and probably for the previous millennium. ${ }^{3}$

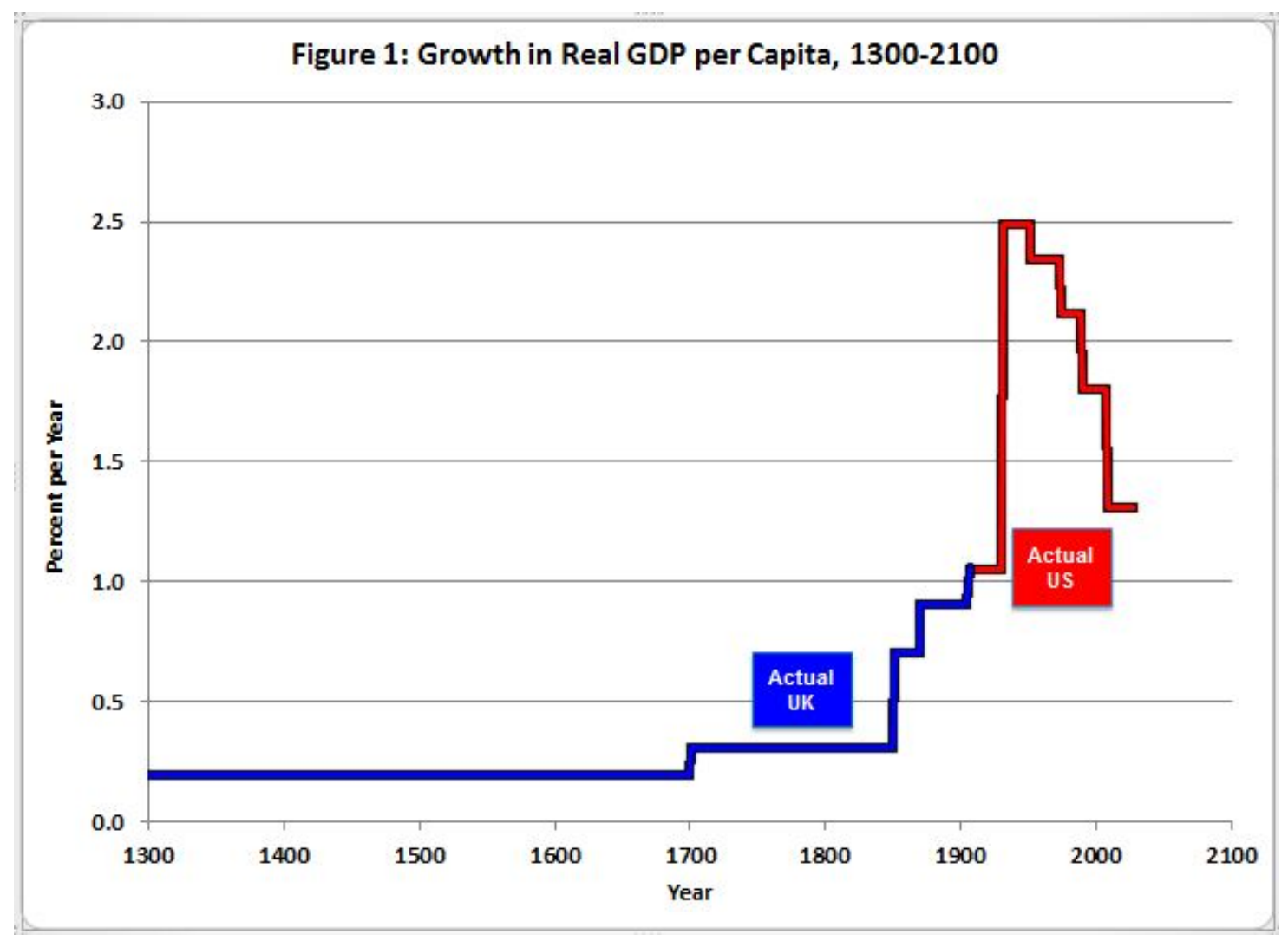

\footnotetext{
${ }^{2}$ British data for 1300-1870 come from Broadberry et al. (2010) and are ratio-linked to Maddison's U.K. data through 1906. U.S. data are based on NIPA Table 1.1.6 back to 1929 and are ratio-linked to annual GDP from Balke-Gordon (1989).

${ }^{3}$ The classic article on very long-run growth is Kremer (1993).
} 
By 1906 growth in Britain had crept up to a bit above one percent per year, and then the U.S. took over frontier leadership. Growth rates for the U.S. are plotted at intervals long enough to eliminate the impact of the business cycle, the Great Depression, and World War II. The slow growth from 1906 to 1928 is a puzzle and may reflect measurement problems, as this was a period when IR \#2 had its greatest initial impact in providing electricity, motor cars, paved roads, running water, and plumbing to urban America. Then the growth rate exploded over the 1928-50 interval encompassing the Great Depression and World War II. Part of this leap forward was due to technological advances developed during the 1930s (Field, 2011), and another part was due to the large share of U.S. 1950 GDP devoted to military expenditures, using weapons, planes, and equipment financed by the government during World War II.

Each of the successive periods after 1950 exhibits a downward step in per-capita real GDP growth, with steps downward marked at 1964, 1972, and 1987. The final step downward is not actual data but a 2007 forecast that I made before the financial crisis of growth for the two decades 2007-27.4 Due to the recession and sluggish recovery, the level of U.S. real GDP per capita is currently running 8 percent below the level implied by that forecast made five years ago.

Now we combine the historical record with a provocative fantasy. Overlaid on the historical record is a smoothly curved green line (Figure 2) which shows growth steadily increasing to the mid-20 $0^{\text {th }}$ century and then declining back to where it started, 0.2 percent per year by the end of the $21^{\text {st }}$ century. The green line is designed both to mimic history but also have a smooth trajectory between now and the year 2100 that makes a soft landing on 0.2 percent growth. Toward the end of this article a few numbers are suggested to indicate the contributions of the six headwinds to a slowdown of growth from the 1.4 percent previous forecast for 2007-27 and the 0.2 percent fantasy forecast for 2100 .

These growth rates are translated into the corresponding levels of per-capita income in the prices of 2005, which for the U.S. in 2007 was $\$ 44,800$, and this is done in Figure 3. The implied level for the U. K. in 1300 was about $\$ 1,150$ in today's prices, and it took five centuries for that level to triple to $\$ 3,450$ in 1800 and more than a century almost to double to $\$ 6,350$ in 1906, the transition year from the U. K. to the U.S. data. After a strangely slow transition to 1929 , the pace picked up. It took only 28 years for the level to double from roughly $\$ 8,000$ to $\$ 16,000$ between 1929 and 1957, and only 31 years for it to double again from $\$ 16,000$ to $\$ 32,000$ in 1988. Even with the steady slowdown in the growth rate after 1988, the forecast level implied by the green line for the year 2100 is $\$ 87,000$, almost double the actual level reached in 2007.

\footnotetext{
${ }^{4}$ This forecast was originally made for a paper at a conference honoring Angus Maddison's $80^{\text {th }}$ birthday that was held in Groningen in October, 2006. The same forecast is contained in Gordon (2010).
} 

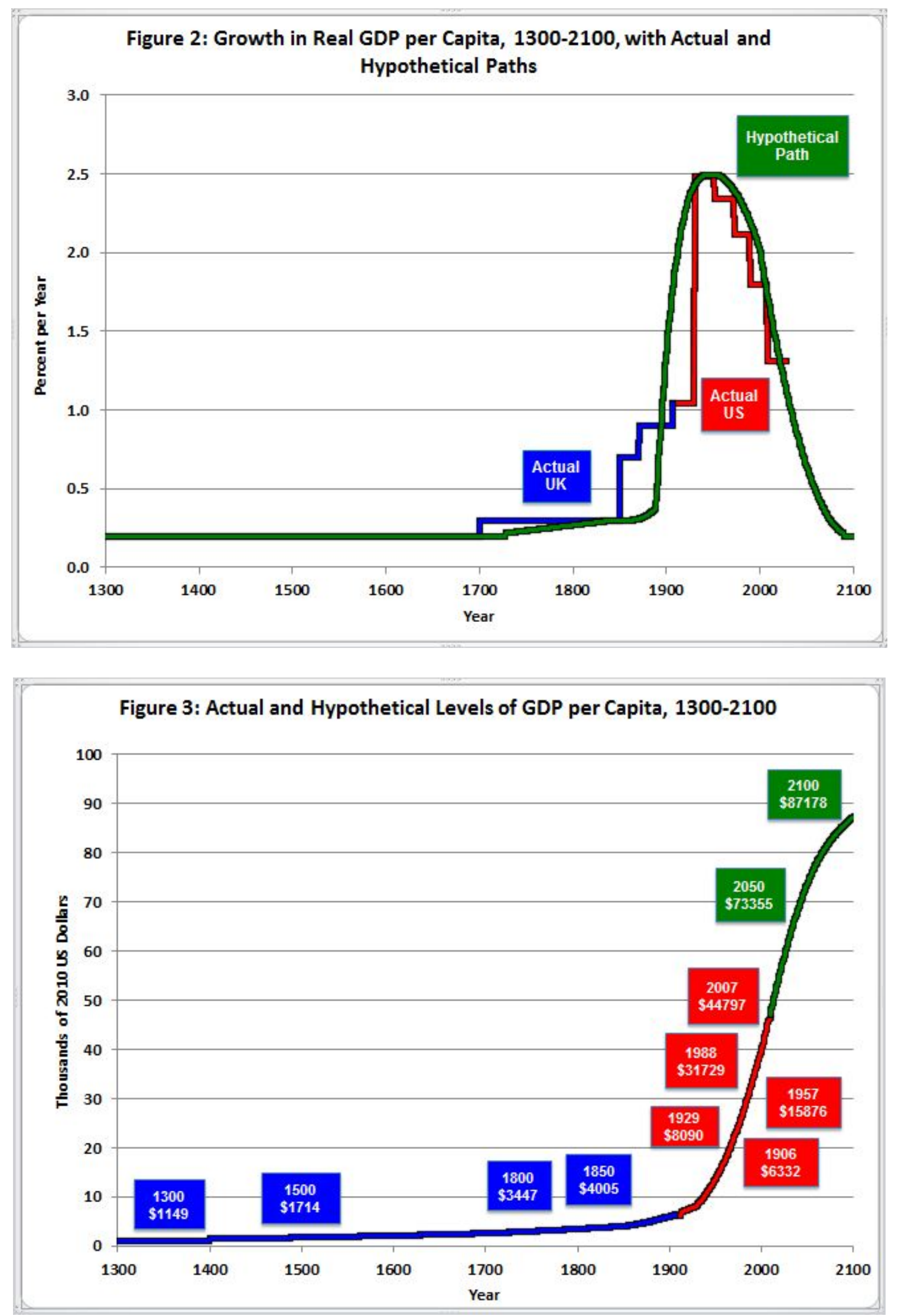
Summarizing, doubling the standard of living took five centuries between 1300 and 1800. Doubling accelerated to one century between 1800 and 1900. Doubling peaked at a mere 28 years between 1929 and 1957 and 31 years between 1957 and 1988. But then doubling is predicted to slow back to a century again between 2007 and 2100. Of course the latter is a forecast, and the rest of this essay provides support for its plausibility.

\section{The Dawn of the Second Industrial Revolution: the Standard of Living in $\mathbf{1 8 7 0}$}

The year 1870 is a natural break point to begin our discussion of the impact of the three industrial revolutions on economic growth. The Civil War was over. The golden spike had been driven in by the silver hammer with the telegraph message instantly sent within seconds to the entire United States and even the United Kingdom. The single-word message was "Done," and it led to the greatest celebration in the history of the United States up to that date, far beyond anything that happened when the Union won a battle in the Civil War. Also for statisticians, 1869 is the first year of the Census of Manufacturing.

A lot of progress had been made by 1870. After centuries when every task was carried out by human and animal effort, individual tasks began to be carried out by machine power, both water and steam, initially in the U. K. The 1844 invention of the telegraph created by far the biggest increase in the speed of communication in human history, and soon continents were linked with undersea cables.

But most aspects of life in 1870 (except for the rich) were dark, dangerous, and involved backbreaking work. There was no electricity in 1870. The insides of dwelling units were not only dark but also smoky, due to residue and air pollution from candles and oil lamps. The enclosed iron stove had only recently been invented and much cooking was still done on the open hearth. Only the proximity of the hearth or stove was warm; bedrooms were unheated and family members carried warm bricks with them to bed.

But the biggest inconvenience was the lack of running water. Every drop of water for laundry, cooking, and indoor chamber pots had to be hauled in by the housewife, and wastewater hauled out. The average North Carolina housewife in 1885 had to walk 148 miles per year while carrying 35 tons of water. ${ }^{5}$ Coal or wood for open-hearth fires had to be carried in and ashes had to be collected and carried out. There was no more important event that liberated women than the invention of running water and indoor plumbing, which happened in urban America between 1890 and 1930.

Were summers better than winters back then? In 1870, the window screen had not yet been invented. In the summer, the windows were open and the insects flew back and forth

\footnotetext{
${ }^{5}$ This fact was first reported in a 1886 survey by the North Carolina Farmers' Alliance and is reported by Strasser (1982, p. 86).
} 
between the outdoor animals and the indoor dining table. It is said that the national bird of the United States in the $19^{\text {th }}$ century was the housefly.

While the railroad connected the cities, there were horses on every urban street. Within the cities, steam power was not practical, so everything was hauled by horses. The average horse produced 20 to 50 pounds of manure and a gallon of urine daily, applied without restraint to stables and streets. The daily amount of manure worked out to between 5 and 10 tons per urban square mile, all requiring disgusting human labor to remove. ${ }^{6}$ The low standard of living reflected not just the small amount that people could purchase but also the amount of effort at the workplace and at home where they had to expend to perform ordinary tasks.

Life expectancy was only 45 years in 1870, compared to 79 years recently. Why? Infant mortality resulted from poor sanitation, water-transmitted diseases, and contaminated milk. The first attempts at urban sanitation infrastructure emptied the waste into the rivers because there was a theory at that time that rivers were self-cleansing. And there were further causes of low life expectancy: hard physical labor and work-related injuries. In 1900, 13,000 people died in railroad deaths, about a quarter of them railroad employees, and others included both passengers - because boilers would blow up-or pedestrians run down by the railroad. There was also violence and lynching.

A crude measure can be developed regarding the quality of work. A uniform set of occupational definitions goes back to 1870. One can go through the list and label each occupation as relatively "pleasant" or "unpleasant." Unpleasant jobs include farming, farm laborers, blue-collar workers, urban laborers, and household servants. Relatively more pleasant were such occupations as sales and clerical work, or professionals and managers. By this classification in 187087 percent of the jobs were unpleasant; but by 2010 only 22 percent were unpleasant.

Each job in the unpleasant category, however, has changed in character toward improved working conditions. In 1870, farmers pushed a plough behind a horse. In 2012, American farmers drive air-conditioned, enclosed John Deere tractors that drive themselves, guided by GPS, and contain computers that automatically drop the seeds.

\section{How the Great Inventions Changed Living and Working Conditions}

The "Great Inventions" of the Second Industrial Revolution (IR \#2) utterly changed living and working conditions, particularly in urban America, within half a century and their full impact was largely complete during the century following 1870 . The inventions can be grouped into five categories: (1) electricity and all its spin-offs; (2) the internal combustion engine and all its subsidiary improvements right up to the interstate highway system; (3)

\footnotetext{
${ }^{6}$ Greene (2008, p. 174).
} 
running water, indoor plumbing, and central heating; (4) rearranging molecules, including everything to do with petroleum, chemicals, plastics, and pharmaceuticals; and finally (5) the set of communication and entertainment devices invented within the remarkably short period between 1885 and 1900, including the telephone, the phonograph, popular photography, radio, and motion pictures.

The effects of these inventions and sub-inventions can be grouped by the particular impact they had on animal and human effort. Motor power replaced animal power. To maintain a horse every year cost approximately the same as buying a horse. Imagine today that for your $\$ 30,000$ car you had to spend $\$ 30,000$ every year on fuel and repairs. That's an interesting measure of how much efficiency was gained from replacing the horses. Gone was the need for unsanitary and repulsive jobs of people who had to remove horse waste.

Much of the inventive effort replaced not just animals but also brute-force human effort: running water replaced hauling water and waste: oil and gas replaced coal and wood; electric hand tools became common by 1910 and 1920; and household appliances began to proliferate with the early washers and refrigerators in the 1920s. Human comfort and convenience benefited by replacing the outhouse, replacing the open-hearth fire, and by the invention of window screens shortly after 1870 . Reading was easier with electric light, and pollution was reduced as natural gas began to be used in place of coal. Shopping, which in 1870 was heavily dominated by monopolistic local general stores in rural areas, was gradually replaced by department stores, supermarkets, and mail-order catalogs.

Another dimension of improvement was speed. By 1870 intercity trains traveled at 25 miles per hour and horse-drawn streetcars with their six-mile per hour pace were beginning to replace less efficient horse-drawn omnibuses that traveled only half as fast. Within a few years the horse-drawn streetcar was replaced by the electric streetcar and the motorbus. All of a sudden in the 1890s and 1900s appeared the Chicago elevated and the New York City subway system, with similar improvements in many other cities.

None of the transportation inventions of the 1870-1900 period were more important than the automobile. Prior to its invention, there was almost no chance for travel by working class families either from the farm to the city, or from the city to the countryside. Ownership of horses and carriages was a privilege limited to the rich and the elite. The automobile changed all that, and even more for farmers than city residents; by 1926 fully 93 percent of Iowa farmers owned motor cars. The range of indirect benefits provided by the automobile is suggested in this quote from Flink (1972, p. 460):

The benefits of automobility were overwhelmingly more obvious: an antiseptic city, the end of rural isolation, improved roads, better medical care, consolidated schools, expanded recreational opportunities, the decentralization of business and residential patterns, a suburban real estate boom, and the creation of a standardized middle-class national culture. 
Starting in 1860 with the horse omnibus traveling at three miles per hour, suddenly by 1904 the express trains of New York's IRT subway line were traveling between stops at 40 miles per hour, and by 1940 the Chicago North Share Railroad traveled between stops at 80 miles per hour. Barely two decades after the Wright Brothers' first 1903 flight, in 1926 a flimsy Swallow biplane flew from Pasco, Washington, to Elko, Nevada, on the first U.S. commercial airline flight, flying 98 pounds of mail at 90 miles per hour. ${ }^{7}$ By 1958, travelers were going 550 miles an hour in a Boeing 707, and today we go not faster than in 1958 but rather slower due to the need to conserve fuel.

Communication and entertainment blossomed with the telegraph, telephone, phonograph, recorded music and, by 1920, the first commercial radio station. In a brief period of time of only about four decades the nickelodeon was replaced by silent movies and then the great technical and creative advances that created Gone With the Wind and The Wizard of Oz in 1939. Television was introduced at the New York World's Fair of 1939-40 and the first TV stations began broadcasting in 1946 as soon as wartime production constraints were lifted.

Life expectancy began to grow rapidly as horse-created diseases were reduced; running water and water-treatment plants largely eliminated water-borne diseases; and regulations and refrigeration prevented the spoilage of milk and meat. The Jungle, Upton Sinclair's sensational muckraking expose of the Chicago stockyards, helped push popular and political sentiment to create the Food and Drug Administration in 1906.

Eventually in the 1930s and 1940s sulfa and antibiotics were invented, but by then life expectancy had turned a decisive corner. Little known is the fact that the annual rate of improvement of life expectancy in the first half of the $20^{\text {th }}$ century was three times as fast as in the last half. Within one century by 1970 life had been utterly changed. The interstate highway system was almost completed. Air conditioning was universal in commerce and widespread in residential homes. Air travel by 1970 had been completely converted to jets with no further increase in speed. Consumer appliances were universal in the United States, with only the microwave oven still waiting to be invented and diffused.

A common feature of this innovative revolution was that many of the improvements could only happen once. Speed of travel was increased from that of the horse to the jet plane in a century but could not happen again. The interior temperature that in 1870 alternated between freezing cold in the winter and stifling heat in the summer reached a year-round 72 degrees Fahrenheit (22C), and that could not happen again. The U.S. was transformed from 75 percent rural to 80 percent urban, and that could not happen again.

\footnotetext{
${ }^{7}$ Walter Varney's tiny airline flew that first Swallow biplane on April 6, 1926. Soon he sold his airline to what by 1931 was called United Airlines, the amalgam of Varney, National, and Boeing Airlines. Always adventurous, he founded Varney Speed Lines in 1934, and this soon became Continental Airlines. In 2010 United and Continental Airlines merged, and so in one of the great retrospective coincidences of American industrial history, Walter Varney can be credited with founding both components of what is now the world's largest airline.
} 
The growth of productivity (output per hour) slowed markedly after 1970. While puzzling at the time, it seems increasingly clear that the one-time-only benefits of the Great Inventions and their spin-offs had occurred and could not happen again. Diminishing returns set in, and eventually all of the subsidiary and complementary developments following from the Great Inventions of IR \#2 had happened. All that remained after 1970 were second-round improvements, such as developing short-haul regional jets, extending the original interstate highway network with suburban ring roads, and converting residential America from windowunit air conditioners to central air conditioning.

\section{The Third Industrial Revolution: Computers and the Internet}

The Third Industrial Revolution (IR \#3) began with the first commercial uses of computers around 1960 and continued through the development of the Internet, the web, and ecommerce in the 1990s. Initially computers shared with the steam engine, the internal combustion engine, and the electric motor the many-faceted benefits of replacing human effort, making jobs easier, less boring, and less repetitive. It may seem surprising that so many of the computer's laborsaving impacts occurred so long ago.

The first industrial robot was introduced by General Motors in 1961. Telephone operators went away in the 1960s. As long ago as 1960 telephone companies began creating telephone bills from stacks of punch cards. Bank statements and insurance policies were soon computer-printed. The first credit card was introduced in the late 1950s and my personal American Express card is still stamped "1968."

By the 1970s, even before the personal computer, tedious retyping had been made obsolete by memory typewriters. Airline reservations systems came in the 1970s, and by 1980 bar-code scanners and cash machines were spreading through the retail and banking industries. Old-fashioned mechanical calculators were quickly discarded as electronic calculators, both miniature and desktop, were introduced around 1970.

The first personal computers arrived in the early 1980s with their word processing, word wrap, and spreadsheets. Word processing furthered the elimination of repetitive typing, while spreadsheets allowed the automation of repetitive calculations. Secretaries began to disappear in economics departments, and professors began to type their own papers. "Moore's Law" proceeded apace and allowed larger document and spreadsheet files to be handled faster. The multiplying power of computer chips was matched by increasing complexity of software, leading to the light-hearted verdict that "What Intel Giveth, Microsoft Taketh Away."

More recent and thus more familiar was the rapid development of the web and ecommerce after 1995, a process largely completed by 2005. Many one-time-only conversions occurred, for instance from card catalogues in wooden cabinets to flat screens in the world's 
libraries and the replacement of punch-hole paper catalogues with flat-screen electronic ordering systems in the world's auto dealers and wholesalers. There was a burst of investment in the late 1990s as every large and small corporation developed its own web site; while many "dot.com" start-ups succumbed to overly optimistic plans, others like Amazon and Google developed business models that rose to dominance in the years after the dot.com stock market bubble peaked in early 2000.

\section{Comparing the Industrial Revolutions: A Thought Experiment}

This account of the role of IR \#2 and IR \#3 share the common feature that many of these transformations could only happen once. Figure 4 is a bar chart showing the average growth rate of U.S. labor productivity over four time intervals: 1891-72, 1972-96, 1996-2004, and 20042012. ${ }^{8}$ These intervals are chosen to reveal the contributions of the industrial revolutions. IR \#2 and its subsidiary developments were able to keep productivity growth going for 81 years between 1891 and 1972. It is puzzling that all the benefits of the computer enumerated above did not prevent the significant productivity growth slowdown by half from 2.3 percent per year during 1891-72 to only 1.4 percent per year during 1972-96. My interpretation is that the spinoff inventions from IR \#2 explain most of the rapid growth of productivity between the 1890s and 1970s, and that diminishing returns to the benefits of these inventions was the basic cause of the post-1972 productivity growth slowdown.

Why did all the computer-driven IR \#3 improvements before 1995 fail to maintain productivity growth at a faster pace despite the fading out of the benefits of IR \#2? In 1987 Robert M. Solow posed his famous paradox, "We can see the computers everywhere except in the productivity statistics." An explanation developed by Daniel Sichel (1997) and others was that back in the 1970s and 1980s computers were just too small a fraction of the capital stock to have a measurable impact on aggregate productivity growth. In short, in its early years IR \#3 was a pipsqueak compared to IR \#2. The contributions to productivity growth made by the first few decades of computer implementation kept the pace of advance in 1972-96 from being even slower than it actually was.

The Internet, web, and e-commerce did, however, make a difference. Productivity growth began to recover in 1996 and by 1999 the arrival of the "new economy" was heralded, with many enthusiasts predicting an impact greater than electric motors or the internal combustion engine. Figure 4 shows that between 1996 and 2004 productivity growth rose from the previous rate of 1.4 percent to 2.5 percent per year, slightly faster than during 1891-72.

\footnotetext{
${ }^{8}$ The concept plotted is total-economy output per hour. This is defined as real GDP divided by an unpublished quarterly BLS series on hours for the total economy, including the private economy, government, and institutions. Percentage logarithmic growth rates are calculated between the first quarter of each of the listed years, e.g., 1948:Q1 to 1972:Q1. To extend the series back from 1948 to 1891, annual NIPA data on real GDP prior to 1929 are ratiolinked to the real GDP data of Balke-Gordon (1989), and the BLS hours data prior to 1948 are ratio-linked to the man-hours data of Kendrick (1961, pp. 330-32).
} 


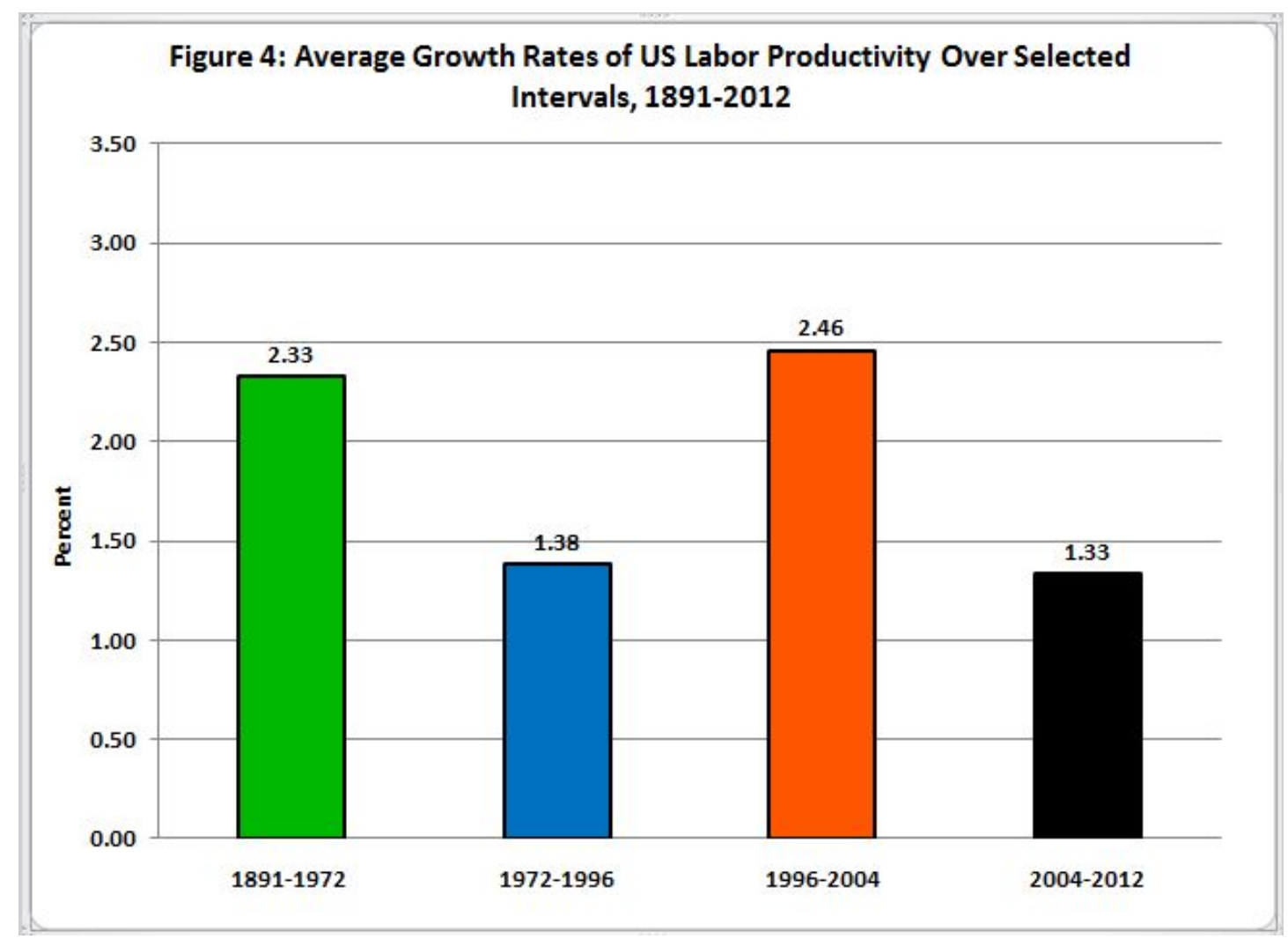

I was (Gordon, 2000) among the skeptics and doubted that the "new economy" would have an impact comparable to the inventions of IR \#2. With 12 additional years of data, it appears that my initial skepticism was appropriate, as the productivity benefits of IR \#3 had faded away by 2004. During the past eight years (2004-12) labor productivity growth has slowed again to almost exactly the same rate as 1972-96, a mere 1.3 percent per annum. The growth rate in the past two years, 2010-12, is even slower, only 0.5 percent. Thus the productivity impact of IR \#3 evaporated after only eight years, compared to the 81 years (18911972) required for the benefits of IR \#2 to have their full impact on productivity and the standard of living. ${ }^{9}$

In the past decade the nature of IR \#3 innovations has changed. The era of computers replacing human labor was largely over, although the role of robots continued to expand in manufacturing, while many airline check-in employees were replaced by e-kiosks. By 2002 ecommerce had already arrived as a source of convenience to consumers that went beyond the selection available in mail-order catalogs, not to mention the speed and ease of ordering.

Attention in the past decade has focused not on labor-saving innovation, but rather on a succession of entertainment and communication devices that do the same things as we could do

\footnotetext{
${ }^{9}$ The same measure of productivity growth for $1872-91$ is only 0.68 percent per year, indicating that the impact of the spreading railroad network did not have the same magnitude of impact on productivity growth as the Great Inventions of IR \#2, which began to have their impact after 1890.
} 
before, but now in smaller and more convenient packages. The iPod replaced the CD Walkman; the smartphone replaced the garden-variety "dumb" cellphone with functions that in part replaced desktop and laptop computers; and the iPad provided further competition with traditional personal computers. These innovations were enthusiastically adopted, but they provided new opportunities for consumption on the job and in leisure hours rather than a continuation of the historical tradition of replacing human labor with machines.

A thought experiment helps to illustrate the fundamental importance of the inventions of IR \#2 compared to the subset of IR \#3 inventions that have occurred since 2002. You are required to make a choice between option A and option B. With option A you are allowed to keep 2002 electronic technology, including your Windows 98 laptop accessing Amazon, and you can keep running water and indoor toilets; but you can't use anything invented since 2002.

Option B is that you get everything invented in the past decade right up to Facebook, Twitter, and the iPad, but you have to give up running water and indoor toilets. You have to haul the water into your dwelling and carry out the waste. Even at 3am on a rainy night, your only toilet option is a wet and perhaps muddy walk to the outhouse. Which option do you choose?

I have posed this imaginary choice to several audiences in speeches, and the usual reaction is a guffaw, a chuckle, because the preference for Option A is so obvious. The audience realizes that it has been trapped into recognition that just one of the many late $19^{\text {th }}$ century inventions is more important than the portable electronic devices of the past decade on which they have become so dependent. ${ }^{10}$

We can convert the productivity growth rates of Figure 4 into the implied levels of productivity. To shorten the horizontal span of the graph, we begin not in 1891 but in 1948 . Figure 5 plots the actual level of productivity (measured in 2005 dollars per hour) from 1948 to 2012 as the wiggly red line, which is barely visible behind three trend lines. The green line shows the 1948-72 trend and when extended to the right shows the level that productivity would have reached in 2012 if that 1948-72 trend had continued. The blue line shows the same thing if the slower 1972-96 trend had continued. The black line begins in 2004 after the benefits of IR \#3 had faded away and shows the 2004-2012 trend, which by definition crosses the actual values in both 2004 and 2012.

The conclusion is startling. If the 1972-96 trend had continued along the blue line, then today's productivity level would have been $\$ 49.60$. The actual level today is $\$ 53.90$, or nine percent higher. That is one way to assess the contribution of the productivity revival of the late 1990s made possible by IR \#3. But if the rapid 1948-72 trend had continued along the green line today's level would have been $\$ 83.20$, fully 69 percent higher than the blue trend. To the extent

\footnotetext{
${ }^{10}$ I have not posed this question to a roomful of 15-year-olds. They could not imagine a world without Facebook. But, then, it is beyond their imaginations to conceive of what it would mean to live without running water, bathrooms, and indoor toilets.
} 
that the rapid green trend was made possible by exploiting the inventions of IR \#2, then the "new economy" of IR \#3 only made up for about 13 percent (9/68) of what we lost after 1972 due to the fading out of benefits from IR \#2 and its many sub-inventions.

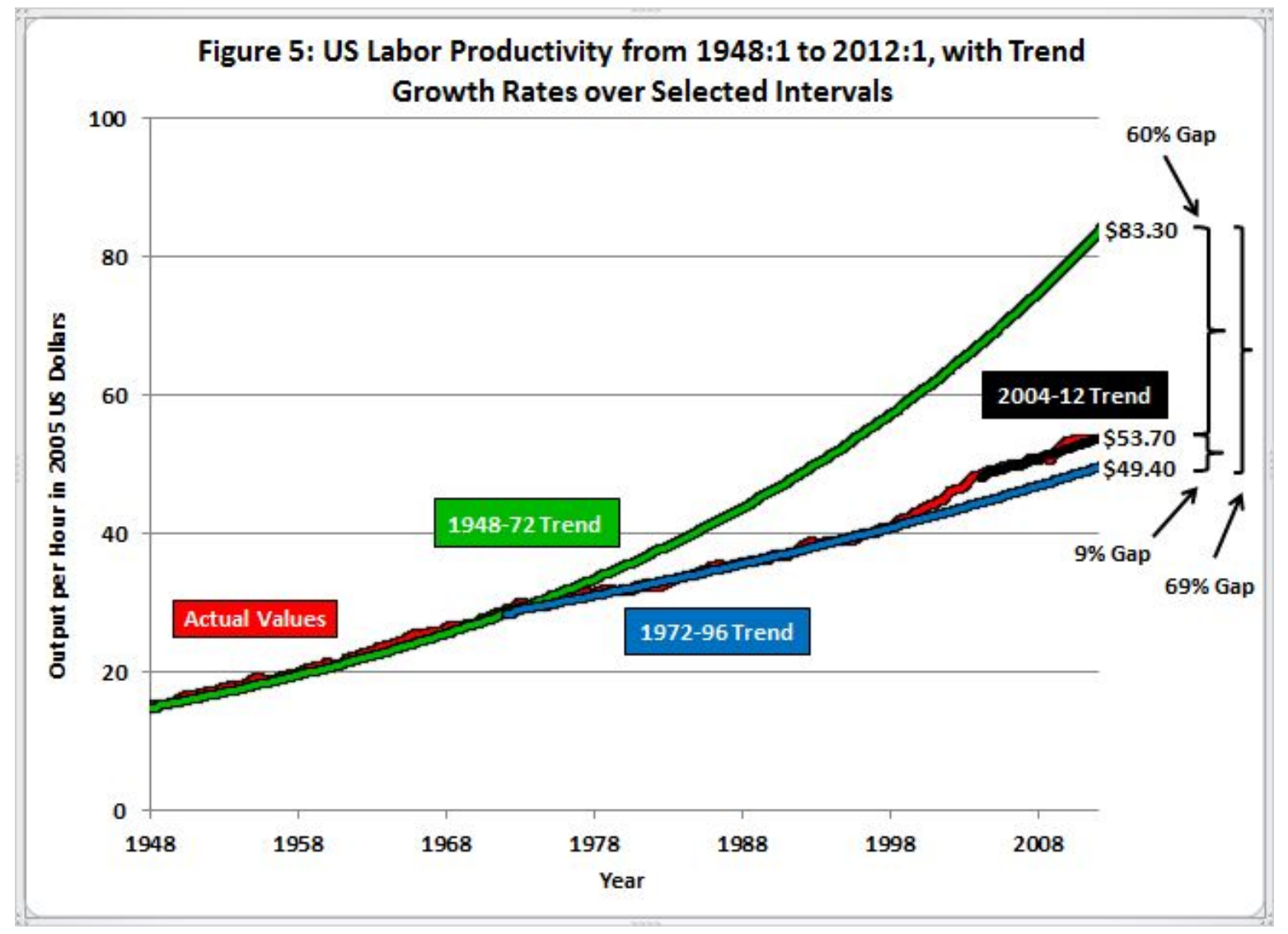

\section{The Future: Faltering Innovation Confronts the Six Headwinds}

The fact that so many fundamental one-time-only inventions have already occurred limits the potential for a continuing stream of equally basic inventions. Such essential improvements of human life as the conversion from rural to urban life, the speed of travel, the temperature of rooms, and the near-elimination of brute-force manual labor, have already been achieved. But no one should step into the trap of predicting that innovation will come to an end.

There are four classic examples in the past of innovation pessimism that turned out to be wildly wrong. In 1876, an internal memo at Western Union, the telegraph monopolists, said, "The telephone has too many shortcomings to be considered as a serious means of communication." In 1927, a year before The Jazz Singer, the head of Warner Brothers said, "Who the hell wants to hear actors talk?" In 1943, Thomas Watson, then president of IBM, said, "I think there is a world market for maybe five computers." And in 1981, in the most famous of 
these ill-fated quotes, Bill Gates himself said in defense of the capacity of the first floppy disks, "640 kilobytes ought to be enough for anyone."

Heeding the warning of these forecasting missteps, let us assume that innovation continues, with such marvels as the driverless Google car on the near term horizon. Research on the genome will surely make progress in the fight against cancer and other diseases. But research for new blockbuster drugs is encountering diminishing returns, with a substantial numbers of failures and rapidly escalating costs of experimentation per successful new drug found. And, just as we should heed the lesson of the four overly pessimistic quotations from the Western Union to Bill Gates, so we should also recall the past overoptimism, including the universal prediction in the late 1940s that within a generation each family would have its own vertical lift-off airplane, a universal society of Jetsons.

Whatever the future of innovation, the U.S. economy still faces six daunting headwinds that will limit future potential growth and hold it below the pace which innovation would otherwise make possible.

Recall that Figure 1, the graph with the blue and red step-like representation of growth rates of real per-capita GDP over long intervals, included a forecast. The final downward step assumed that growth in real GDP per capita would slow from the actual 1.8 percent rate recorded during 1987-2007, to a lower 1.4 percent rate. ${ }^{11}$ This slowdown in growth already takes into account the first two headwinds.

(1) The "demographic dividend" is now in reverse motion. The original dividend was another one-time-only event, the movement of females into the labor force between 1965 and 1990, which raised hours per capita and allowed real per-capita real GDP to grow faster than output per hour. But now the baby-boomers are retiring, no longer included in the tally of total hours of work but still included in the population. Thus hours per capita are now declining, and any tendency for life expectancy to grow relative to the average retirement age will further augment this headwind. By definition, whenever hours per capita decline, then output per capita must grow more slowly than productivity.

(2) The second headwind already taken into account in the 2007-27 forecast is the plateau in educational attainment in the U.S. reached more than 20 years ago, as highlighted in the path-breaking work of Claudia Golden and Lawrence Katz (2008). The U.S. is steadily slipping down the international league tables in the percentage of its population of a given age which has completed higher education. This combines several problems. One is the cost disease in higher education, that is, the rapid increase in the price of college tuition relative to

\footnotetext{
${ }^{11}$ The 2007-27 forecast was originally made at a conference in Groningen in October, 2006, at a conference in honor of Angus Maddison's 80 ${ }^{\text {th }}$ birthday. It is reproduced in Gordon (2010, Table 10) and does not take into account any downward deflection in the growth path that might have been caused by the recent recession and slow recovery. As of 2012:Q1 real GDP per capita is 9\% below that forecast path. That is, either the output gap is minus $9 \%$, or the growth rate of potential real GDP per capita has slowed below a 1.4 percent annual growth rate assumed in the forecast.
} 
the prices of other goods. This cost inflation in turn leads to mounting student debt, which is increasingly distorting career choices and deterring low-income people from going to college at all. Not everybody gets a scholarship.

At the secondary level the OECD PISA test results for 37 nations had the U.S. recently ranked as ranked as $21^{\text {st }}$ in reading, $31^{\text {st }}$ in math, and $34^{\text {th }}$ in science. There is an ongoing achievement gap between whites and Asians on the one hand and Hispanics and Blacks on the other, while the Hispanic percentage of our nation's schoolchildren keeps increasing, dragging down the national average. Making matters worse is a new and growing gap between the educational preparation and achievement of American girls and boys; the female share of college graduates is now up to 58 percent.

The remaining four headwinds are not taken into account in the forecast of 1.4 percent per-capita GDP growth for 2007-27 but are equally daunting. These lead us to alter the defining metric of future growth from income per capita to consumption per capita for the bottom 99 percent of the income distribution.

(3) The most important quantitatively in holding down the growth of our future income is rising inequality. The growth in median real income has been substantially slower than all of these growth rates of average per-capita income discussed thus far. The Berkeley web site of Emmanuel Saez provides the startling figures. From 1993 to 2008, the average growth in real household income was 1.3 percent per year. But for the bottom $99 \%$ growth was only 0.75 , a gap of 0.55 percent per year. The top one percent of the income distribution captured fully $52 \%$ of the income gains during that 15-year period. If what we care about when we talk about "consumer well being" is the bottom 99 percent, then we must deduct 0.55 percent from the average growth rates of real GDP per capita presented here and elsewhere.

(4) The interaction between globalization and ICT is a daunting headwind. Its effects include outsourcing of all types, from call centers to radiologist jobs. Foreign inexpensive labor competes with American labor not just through outsourcing, but also through imports. And these imports combine lower wages in emerging nations with growing technological capabilities there. This is nothing more than the Hecksher-Ohlin-Samuelson factor-price equalization theorem at work, and it inevitably has a damaging effect on the nations with the highest wage level, i.e., the United States.

(5) Energy and the environment represent the fifth headwind. Part of any effort to cope with global warming represents a payback for past growth. In 1901 the environment was not a priority and the symbol of a prosperous city was a drawing of a factory spewing pure black smoke out of its chimneys. The consensus recommendation of economists to impose a carbon tax in order to push American gasoline prices up toward European levels will reduce the amount that households have left over to spend on everything else (unless it is fully rebated in lump-sum or other payments). India and China are both growing more rapidly than the U.S. and taken together those two nations are responsible for double the carbon emissions of the U.S., 
but they resist suggestions that their growth to high-income status should be curtailed by energy restrictions, since today's rich nations of North America, Europe, and Japan were not regulated in the same way during their $20^{\text {th }}$ century period of high growth. ${ }^{12}$

(6) The twin household and government deficits represent the final headwind. Already in 2007 U.S. households suffered from an unprecedented overhang of debt equal to 133 percent of disposable income. The government debt was then manageable but has since begun to explode. Consumers have gradually been paying off debt, and this is one reason why the economic recovery has been so tepid. As a matter of arithmetic the ratio of government debt to GDP can be reduced by a mix of higher taxes, lower expenditures, and lower entitlement benefits (including higher retirement ages). But the same arithmetic implies that higher taxes and/or lower transfers reduces the growth rate of real household disposable income relative to that of real GDP.

\section{An Exercise in Subtraction}

We began with the tantalizing (and frightening) suggestion in the green line of Figure 2 that per-capita real GDP growth could slow down to a rate of a mere 0.2 percent by 2100 . How large might be the numerical effect of the six headwinds? A plausible set of numbers can be constructed to reduce the growth rate of real per-capita consumption of the bottom 99 percent of the income distribution down to 0.2 percent per year, but this "exercise in subtraction" needs to be qualified carefully (the qualifications come at the end).

Although the central theme of this article is that innovation does not have the same potential to create growth in the future as in the past, nevertheless let us start by assuming that future innovation propels growth in per-capita real GDP at the same rate as in the two decades before 2007, about 1.8 percent per year. This strains credulity as a forecast for the future, in that the ICT-driven internet productivity revival of 1996-2000 is included in the performance outcome of the two decades 1987-2007. To start a forecast for 2007-27 at the same growth ratemakes the heroic assumption that another invention with the same productivity impact of the internet revolution is about to appear on the near-term horizon. Thus our starting point is quite optimistic.

Baby-boomer retirement (the reversal of the demographic dividend) brings us down to 1.6 and the failure of educational attainment to continue its historical rise takes us to 1.4 percent. These estimates come from government estimates of future labor-force growth in the wake of baby-boomer retirements, and the impact of the plateau in educational attainment comes from the work of Dale Jorgenson and his collaborators. In Figure 6 the first (black) bar registers future growth of 1.8 percent per year, the same as during 1987-2007. The next two grey bars reduce growth to take account of demography and education.

\footnotetext{
${ }^{12} 2010$ estimated $\mathrm{CO}_{2}$ emissions were 10.3 billion tons for China and India compared to 5.5 billion for the U.S. The source is the Carbon Dioxide Information Analysis Center, cdiac.omi.gov.
} 


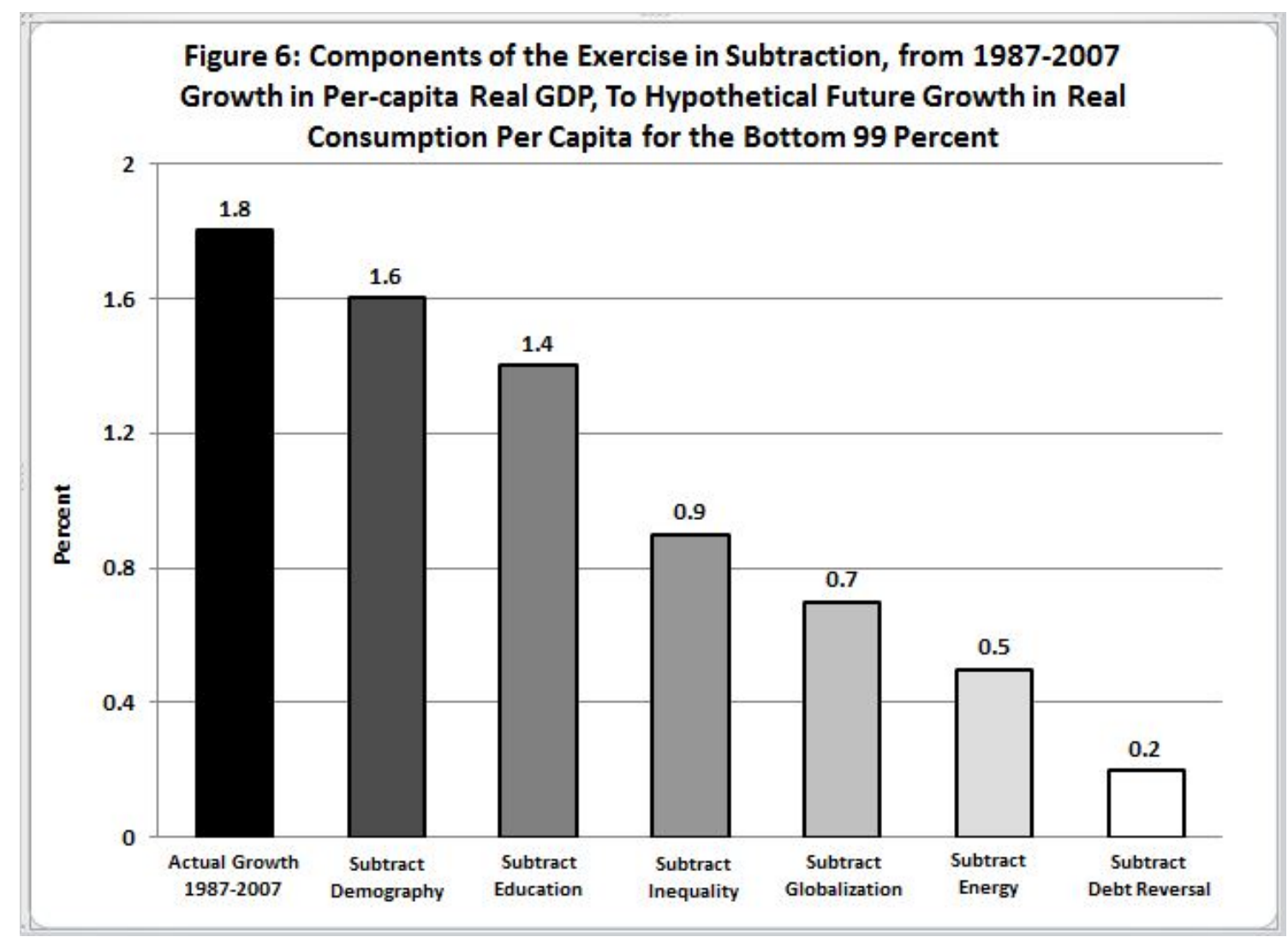

If inequality continues to rise as it did in the last two decades, income for the bottom 99 percent of the income distribution will grow about half a point slower than 1.4 percent, bringing us down to 0.9. Globalization could continue to hollow out middle-level jobs, bringing the rate down to $0.7 .{ }^{13}$ Higher energy taxes could bring the rate down to 0.5. And a combination of consumer debt repayments, income tax increases, and reduced transfer payments, could plausibly reach the 0.2 percent annual rate assumed by the hypothetical green line in Figure 2 . These final subtractions would not necessarily reduce real GDP growth but would force real consumption of the bottom 99 percent of the income distribution to grow more slowly than real GDP as debt is repaid.

The particular numbers don't matter, and there is no magic in the choice of 0.2 percent as the long-run growth rate. That was chosen for "shock value" as the rate of growth for the U.K. between 1300 and 1700. Any other number below 1.0 percent could be chosen and it would represent an epochal decline in growth from the U.S. record of the last 150 years of 2.0 percent annual growth rate in output per capita. ${ }^{14}$

\footnotetext{
${ }^{13}$ In this interpretation, globalization has two effects. One is that it increases inequality, but the other is that it reduces the overall growth rate of average income through the factor-price-equalization process.

${ }^{14}$ Real GDP per capita was \$2,605 in 1860 and \$43,728 in 2007, for a compound annual growth rate of 1.91 percent. That growth rate was a higher 2.17 percent between 1929 and 2007.
} 


\section{What to do About It?}

Volumes have been and will be written on all the issues identified here, and thus it is beyond the scope of this short article to make any serious attempt to provide solutions.

Some of the headwinds contain a sense of inevitability. The most daunting is headwind (4), the interplay between globalization and modern technology, which accelerates the process of catching up of the emerging markets and the downward pressure on wages and real incomes in the advanced nations. In the U.S. the process of downward wage adjustment continues apace as southern states lure foreign auto and aircraft manufacturers with the promise that pesky unions will not be a problem and that wages can be lower than in northern unionized states. This in turns puts pressure on legacy firms in the north to introduce two-tier wage systems that pay new entrants half the traditional union wage, as has occurred in the Midwest auto industry in the past few years. The "revival of American manufacturing" is heralded in the media without recognition that this is part of an ongoing process that erodes the number of highpaying middle-class jobs available to those without a college education.

Globalization does not reduce the growth of all American wages; it hits the middle hardest. ${ }^{15}$ Top executives of multinational industrial and financial firms can enjoy rising incomes based on their firms' reach across the world. The CEOs of Coca-Cola and Boeing enjoy a worldwide market, and the rise of the emerging markets is an opportunity rather than a threat to them and adds to their bonuses and value of their stock options.

Energy and environmental issues (headwind 4) are also related to the rise of the emerging markets. China and India contribute more to the growth of carbon emissions and to global warming than does the U.S. but are naturally reluctant to have their chance to leap into the ranks of the advanced nations set back by high carbon taxes. They argue with some justification that "no foreign power in 1900 told American steel mills to install expensive emissions-reducing devices, so why should we at the same stage of development be asked to do so?" Beijing's notoriously polluted air, at least so far, does not prevent San Francisco from enjoying sparkling skies but it does contribute to global warming.

There is also an inevitability to the subtraction from growth implied by headwind (6), the future repayment of consumer and government debt. U.S. consumption grew faster than real GDP over a long period, fueled by increasing consumer and government debt, a process that cannot continue forever. Over a substantial number of years in the future consumption must grow more slowly than production.

\footnotetext{
${ }^{15}$ David Autor and his co-authors capture best the "polarization” hypothesis that divides employees into a top, a middle, and a bottom, and predicts losses of jobs and relative wages in the middle. See Autor, Katz, and Kearney (2008) and Acemoglu and Autor (2012).
} 
Regarding the educational headwind (2), successive American governments have attempted to find solutions to inadequate educational outcomes at the elementary and secondary level, including "No Child Left Behind" and "Race to the Top," without as yet achieving convincing improvements, especially for low-income children. Less attention has been paid to cost inflation in higher education, which has resulted in part from an arms-warlike explosion of expenditure by many universities, private and public alike, to raise their league table ranking by building ever more lavish laboratory and athletic facilities.

It is headwind (1), the demographic turnaround, that seems on the surface to be the most inevitable but is could potentially be counteracted. The retirement of the baby boomers causes hours per capita to decline and thus reduces growth of income per capita relative to productivity. A method to raise hours per capita is to increase the ratio of those of working age to those of retirement age. As a matter of arithmetic, this could be achieved by a more rapid inflow of immigration.

One potential option would be unlimited immigration of high-skilled workers. As Steve Jobs is reported to have told Barack Obama shortly before he died, "we should staple a green card to the diploma of every foreign worker who attains a graduate degree in science or engineering." For decades Canada has encouraged the immigration not only of skilled applicants but also those who are already rich and by so doing has transformed its culture from British colonial blandness to international world-class diversity.

Much more controversial is the question of unskilled immigration, which suggests a provocative question. Why was unlimited immigration into the U.S. so successful throughout the $19^{\text {th }}$ century, until it was stopped by restrictive legislation in the 1920 s, yet could not be considered as a plausible public policy today? Unlimited immigration before 1913 did not cause mass unemployment. Immigrants were extremely well informed about the availability of employment in the U.S. economy. They arrived when the economy was strong and postponed their arrival (or returned to their home countries) when the economy was weak. ${ }^{16}$

There are more than enough provocative ideas in this article, but I conclude with another. My guess is that a Canadian or Swedish economist looking at the past and future of his or her country would not be nearly so alarmed. Why not? What are the differences in environment, resources, legacy history, policies, and culture that create their relative optimism? Experts on other countries are welcome to contribute their own reactions to this diagnosis of the successful "American century" and the possibility that future economic growth may gradually sputter out.

\footnotetext{
${ }^{16} \mathrm{I}$ have found in unpublished work a surprisingly high correlation between annual immigration as a percent of the U.S. population and detrended annual real GDP for the period 1865-1913.
} 


\section{REFERENCES}

Acemoglu, Daron and Autor, David (2012). “What Does Human Capital Do? A Review of Goldin and Katz's The Race between Education and Technology," Journal of Economic Literature 50 (June, no. 2), 426-63.

Autor, David H., Katz, Lawrence F., and Kearney, Melissa S. (2008). “Trends in U.S. Wage Inequality: Re-Assessing the Revisionists," Review of Economics and Statistics 90 (May, no. 2), 300-23.

Balke, Nathan S., and Gordon, Robert J. (1989). “The Estimation of Prewar GDP: Methodology and New Results," Journal of Political Economy 97 (February), 38-92.

Broadberry, Stephen N., Campbell, Bruce, Klein, Alexander, Overton, Mark, and van Leeuwen, Bas (2010). “British Economic Growth, 1270-1870." University of Warwick working paper, July 14. Accessed from

Eh.net/eha/system/files/Broadberry.pdf.

Field, Alexander J. (2011). A Great Leap Forward: 1930s Depression and U.S. Economic Growth. New Haven and London: Yale University Press.

Flink, James J. (1970). America Adopts the Automobile, 1895-1910. Cambridge: The MIT Press.

Goldin, Claudia, and Katz, Lawrence F. (1998). The Race Between Education and Technology. Cambridge and London: Belknap Press of Harvard University Press.

Gordon, Robert J. (2000). “Does the New Economy Measure Up to the Great Inventions of the Past?" Journal of Economic Perspectives 14 (Fall, no. 4), 49-74.

Gordon, Robert J. (2010). "Revisiting U.S. Productivity Growth over the Past Century with a View of the Future," NBER Working Paper 15834, March.

Greene, Ann Norton (2008). Horses at Work: Harnessing Power in Industrial America. Cambridge and London: Harvard University Press.

Kendrick, John W. (1961). Productivity Trends in the United States. Princeton: Princeton University Press for NBER.

Kremer, Michael (1993). "Population Growth and Technological Change: One Million B.C. to 1990," Quarterly Journal of Economics 108 (August, no. 3), 681-716.

Sichel, Daniel (1997). The Computer Revolution: An Economic Perspective. Washington: Brookings. 
Strasser, Susan (1982). Never Done: A History of American Housework. New York: Pantheon. 